\title{
Late Ediacaran Redox Stability and Metazoan Evolution
}

\section{Citation}

Johnston, David T., S. W. Poulton, T. Goldberg, V. N. Sergeev, V. Podkovyrov, N. G. Vorob'eva, A. Bekker, and Andrew Herbert Knoll. 2012. Late Ediacaran redox stability and metazoan evolution. Earth and Planetary Science Letters 335-336:25-35.

\section{Published Version}

doi:10.1016/j.epsl.2012.05.010

\section{Permanent link}

http://nrs.harvard.edu/urn-3:HUL.InstRepos:10860657

\section{Terms of Use}

This article was downloaded from Harvard University's DASH repository, and is made available under the terms and conditions applicable to Open Access Policy Articles, as set forth at http:// nrs.harvard.edu/urn-3:HUL.InstRepos:dash.current.terms-of-use\#OAP

\section{Share Your Story}

The Harvard community has made this article openly available.

Please share how this access benefits you. Submit a story.

Accessibility 


\section{Late Ediacaran redox stability and metazoan evolution}

3 D.T. Johnston ${ }^{1}$, S.W. Poulton ${ }^{2}$, T. Goldberg ${ }^{3}$, V.N. Sergeev ${ }^{4}$, V. Podkovyrov ${ }^{5}$, N.G. Vorob'eva ${ }^{4}$, 4 A. Bekker ${ }^{6}$, A.H. Knoll ${ }^{1}$

$6{ }^{2}$ School of Civil Engineering and Geosciences, Newcastle University, Drummond Building, Newcastle upon Tyne,

$12{ }^{6}$ Department of Geological Sciences, University of Manitoba, 125 Dysart Rd., Winnipeg, MB R3T 2N2, Canada 
15 Abstract: The Neoproterozoic arrival of animals fundamentally changed Earth's biological and

16 geochemical trajectory. Since the early description of Ediacaran and Cambrian animal fossils, a

17 vigorous debate has emerged about the drivers underpinning their seemingly rapid radiation.

18 Some argue for predation and ecology as central to diversification, whereas others point to a

19 changing chemical environment as the trigger. In both cases, questions of timing and feedbacks

20 remain unresolved. Through these debates, the last fifty years of work has largely converged on

21 the concept that a change in atmospheric oxygen levels, perhaps manifested indirectly as an

22 oxygenation of the deep ocean, was causally linked to the initial diversification of large animals.

23 What has largely been absent, but is provided in this study, is a multi-proxy stratigraphic test of

24 this hypothesis. Here, we describe a coupled geochemical and paleontological investigation of

25 Neoproterozoic sedimentary rocks from northern Russia. In detail, we provide iron speciation

26 data, carbon and sulfur isotope compositions, and major element abundances from a

27 predominantly siliciclastic succession (spanning $>1,000$ meters) sampled by the Kel'tminskaya-

281 drillcore. Our interpretation of these data is consistent with the hypothesis that the $p \mathrm{O}_{2}$

29 threshold required for diversification of animals with high metabolic oxygen demands was

30 crossed prior to or during the Ediacaran Period. Redox stabilization of shallow marine

31 environments was, however, also critical and only occurred about 560 million years ago (Ma),

32 when large motile bilaterians first enter the regional stratigraphic record. In contrast, neither

33 fossils nor geochemistry lend support to the hypothesis that ecological interactions altered the

34 course of evolution in the absence of environmental change. Together, the geochemical and

35 paleontological records suggest a coordinated transition from low oxygen oceans sometime

36 before the Marinoan ( $635 \mathrm{Ma})$ ice age, through better oxygenated but still redox-unstable

37 shelves of the early Ediacaran Period, to the fully and persistently oxygenated marine 
38 environments characteristic of later Ediacaran successions that preserve the first bilaterian

39 macrofossils and trace fossils.

$41 \quad 1.0$ INTRODUCTION

The hypothesis that increased oxygen availability facilitated Ediacaran (635-542 Ma)

43 metazoan evolution dates back more than half a century (Cloud and Drake, 1968; Nursall, 1959).

44 This hypothesis posits that an increase in the oxygen content of shallow-marine environments

45 was physiologically necessary for the emergence of large, highly energetic animals (Raff and

46 Raff, 1970; Rhoads and Morse, 1971). Ecological and physiological observations place lower

47 dissolved oxygen (DO) limits for ocean waters in which different types of animals can live (e.g.,

48 (Diaz and Rosenberg, 1995; Levin, 2003)). They further make predictions about body shape in

49 early animals, based on diffusion length-scales for organisms that lack a circulatory system for

50 bulk oxygen transport (Knoll, 2011; Payne et al., 2011; Raff and Raff, 1970; Runnegar, 1991).

51 Together, then, these physiological requirements for oxygen predict that geochemical evidence

52 for well-oxygenated marine waters should coincide with or slightly antedate fossil records of

53 animals with high oxygen demand.

54 A growing suite of redox-related geochemical tools is now available to test the oxygen-

55 facilitation hypothesis. For instance, reconstructions of the iron and sulfur cycles in Ediacaran

56 strata of Newfoundland suggest a broad consistency between oxygenation and animal

57 diversification (Canfield et al., 2007). There, deep-water axial turbidites with low overall

58 organic carbon contents preserve a shift in the distribution of iron minerals that bespeaks

59 increased DO. This inferred change in redox structure is placed atop the $\sim 580$ Ma glacial deposit 
60 of the Gaskiers Formation and is followed by the appearance of Ediacaran macrofossils through

61 the overlying Drook, Briscal and Mistaken Point formations. A similar geochemical formula

62 was applied to fossil-bearing sections from South China and the Yukon (McFadden et al., 2008;

63 Narbonne and Aitken, 1990), however the relationship between the fossil record and redox

64 transitions in these basins, especially as they relate to Newfoundland (Canfield et al., 2007), is

65 less clear cut. Correlations among these basins and their stratigraphic successions are

66 challenging, and the postulated role of sulfide as a key toxin in basins developed along the

67 continental margin of the South China craton further complicates physiological interpretations

68 (Li et al., 2010).

69 Thus, the lack of first-order geochemical coherence among these localities, perhaps due

70 in part to locally variable biogeochemical fluxes (Johnston et al., 2010; Kah and Bartley, 2011),

71 means that the direct role that oxygen played in the timing of both local and global animal

72 diversification remains to be fully elucidated. Given this, it is important to acknowledge models

73 of eumetazoan innovation that bypass oxygen entirely and call upon ecology as the primary

74 driver (Butterfield, 2009; Peterson and Butterfield, 2005; Stanley, 1973). In addressing the role

75 of oxygen through the application of robust geochemical techniques, both hypotheses can

76 ultimately be tested.

77 Environmental and ecological hypotheses make distinct predictions about the sequence of

78 biological and geochemical changes, which can be tested through detailed geochemical analyses

79 of fossil-bearing Ediacaran strata. This forms the premise for our current study of Ediacaran

80 marine sediments from the Eastern European Platform (EEP). This succession hosts some of the

81 most exquisite examples of early animal life (Fedonkin et al., 2007; Fedonkin and Waggoner,

82 1997; Martin et al., 2000) and offers a prime opportunity to reconstruct oceanic redox conditions 
83 through the application of a range of geochemical methods. Here, we thus revisit both the

84 oxygen facilitation and ecology hypotheses through the application of iron, sulfur, and carbon 85 geochemistry, bulk elemental data, and rigorous statistical analysis.

\subsection{GEOLOGICAL SETTING}

The Kel'tminskaya-1 drillhole, located near the Dzhezhim-Parma uplift in northern

89 Russia records $\sim 5,000$ meters of upper Neoproterozoic and Paleozoic strata that accumulated

90 along the northeast margin of the East European Platform (Fig. 1). The lowermost $2000 \mathrm{~m}$ of the

91 core contains a mixed carbonate and siliciclastic succession deposited in a shallow-marine

92 setting, correlated bio- and chemo-stratigraphically to the Cryogenian (850-635 Ma) Karatau

93 Group in the Ural Mountains (Raaben and Oparenkova, 1997; Sergeev, 2006; Sergeev and

94 Seong-Joo, 2006). Age constraints for this part of the succession are limited, but stromatolites,

95 vase-shaped microfossils (Maslov et al., 1994; Porter et al., 2003) and correlation to Pb-Pb dated

96 carbonate rocks of the Min'yar Formation in the Ural Mountains suggest an age of $780 \pm 85 \mathrm{Ma}$

97 (Ovchinnikova et al., 2000).

98 Unconformably overlying Cryogenian strata, and thus separated by $>100$ million years, 99 are siliciclastics of the Vychegda, Redkino and Kotlin formations. The Vychegda Formation, a $100600 \mathrm{~m}$ thick succession, is dominated by interbedded sandstone, siltstone and shale suggestive of 101 mid-shelf deposition. Diverse large ornamented microfossils first appear low in this unit (at $1022779 \mathrm{~m}$ ) and indicate an Ediacaran age (Vorob'eva et al., 2009b) (Fig. 1). No Sturtian or 103 Marinoan-aged diamictites are present in the drillcore, complicating placement of the 104 Cryogenian-Ediacaran boundary. However, typically pre-Ediacaran microfossils occur in mixed 
105 coastal siliciclastic rocks in the lowermost six meters of the Vychegda Formation, suggesting

106 that the period boundary is marked by a cryptic unconformity just above these beds (Vorob'eva

107 et al., 2009a, b).

108 The exact duration of the proposed hiatus is unclear, however overlying Vychegda shales,

109 interpreted as mid-shelf deposits (Vorob'eva et al., 2009a, b), contain a diverse assemblage of

110 large, highly ornamented organic-walled microfossils akin to the Ediacaran Complex

111 Acanthomorph-dominated Palynoflora (ECAP (Grey, 2005)). In central and southern Australia

112 (Grey and Calver, 2007; Grey et al., 2003), the ECAP assemblage populates a restricted temporal

113 interval, occupying beds that overlie the ca. 580 Ma Acraman impact layer, but underlie the

114 strongly negative C-isotopic excursion of the Wonoka Formation (correlated with the Shuram

115 anomaly in Oman). Well above this interval, diverse Ediacaran macrofossils appear. The same is

116 true in China (Jiang et al., 2007; McFadden et al., 2008), Subhimalayan India (Kaufman et al.,

117 2006), and the Patom region of Siberia (Pokrovskii, 2006; Sergeev et al., 2011). Detrital zircons

118 also constrain ECAP acritarchs in the Hedmark Group, Norway to be younger than 620+/-14 Ma

119 (Bingen et al., 2005), consistent with other results. Taken together, these observations most

120 conservatively suggest that the Vychegda Formation was deposited during the Ediacaran Period,

121 before $558 \mathrm{Ma}$, a U-Pb constraint provided from the Redkino Formation and discussed below.

122 Given the distribution of ECAP microfossils elsewhere, we suggest that the majority of

123 Vychegda Formation deposition took place between 580 and $558 \mathrm{Ma}$.

124 Siliciclastic rocks in the upper $1000 \mathrm{~m}$ of the Kel'tminskaya-1 drillhole correlate with the

125 Redkino and Kotlin successions preserved across the EEP (Sokolov and Fedonkin, 1990).

126 Redkino rocks lack highly ornamented microfossils but preserve an exceptional record of

127 Ediacaran macrofossils, including Kimberella, widely considered to be the earliest known 
128 bilaterian animal (Fedonkin et al., 2007; Fedonkin and Waggoner, 1997) (Fig. 1). Additional

129 information about the paleobiology of Kel'tminskaya-1 core material can be found in (Vorob'eva

130 et al., 2009a, b). U-Pb dates on zircons in Redkino ash beds indicate ages of 555.3 \pm 0.3 Ma near

131 the top of the succession (Martin et al., 2000) and $558 \pm 1$ Ma toward its base (Grazhdankin,

132 2003). Biostratigraphy places the Proterozoic-Cambrian boundary at or near the top of the

133 Kotlin succession.

135 3.0 METHODS

136 Iron speciation was performed following a calibrated extraction technique (Poulton and

137 Canfield, 2005). This method targets operationally defined iron pools, such as iron carbonate

$138\left(\mathrm{Fe}_{\mathrm{carb}}\right.$ : ankerite and siderite), $\mathrm{Fe}^{3+}$ oxides $\left(\mathrm{Fe}_{\mathrm{ox}}\right.$ : goethite and hematite $)$ and mixed valence iron

139 minerals $\left(\mathrm{Fe}_{\mathrm{mag}}\right.$ : magnetite). Pyrite iron $\left(\mathrm{Fe}_{\mathrm{py}}\right)$ and sulfur, as well as acid volatile sulfur (AVS;

140 below detection in these samples) were extracted via traditional distillation techniques (Canfield

141 et al., 1986). Together, these pools define a suite of minerals that can be considered

142 biogeochemically available, or highly reactive $(\mathrm{FeHr})$ towards reductive dissolution in surface

143 and near-surface environments $\left(\mathrm{FeHr}=\mathrm{Fe}_{\mathrm{carb}}+\mathrm{Fe}_{\mathrm{ox}}+\mathrm{Fe}_{\mathrm{mag}}+\mathrm{Fe}_{\mathrm{py}}\right)$ (Poulton et al., 2004a).

144 Total Fe (FeT) additionally comprises a largely unreactive silicate iron pool (FeU), delivered to

145 the marine environment via weathered detrital fluxes (i.e., $\mathrm{FeHr}+\mathrm{FeU}=\mathrm{FeT}$ ). Both pools are

146 classically defined in relation to their reactivity toward dissolved sulfide (Canfield et al., 1992;

147 Poulton et al., 2004b). Total Fe contents were derived from both $\mathrm{HF}-\mathrm{HClO}_{4}-\mathrm{HNO}_{3}$ extractions

148 and standard XRF analyses. X-ray fluorescence also provided major element chemistry, most 
149 notably $\mathrm{Al}, \mathrm{Ti}, \mathrm{K}, \mathrm{Na}, \mathrm{Si}, \mathrm{Mg}, \mathrm{Mn}$, and $\mathrm{P}$ (performed at UMass Amherst). All aqueous Fe

150 analyses were performed by AAS, with a RSD of $<5 \%$ for all stages.

151 Sulfur isotope analyses were performed by combusting sulfide precipitates (see $\mathrm{Fe}_{\mathrm{py}}$

152 above) to $\mathrm{SO}_{2}$ and then run via continuous-flow on a Thermofinnigan Delta $\mathrm{V}$ with an analytical

153 reproducibility of $0.2 \%$, normalized to VCDT. Carbon isotopes were performed on splits of the

154 same bulk sample. Prior to carbon isotope analyses, samples were decalcified with a $10 \% \mathrm{HCl}$

155 pre-treatment. Decalcified samples were analyzed for organic carbon isotopes $\left(\delta^{13} \mathrm{C}_{\text {org }}\right)$ and total

156 organic carbon contents (TOC) via combustion to $\mathrm{CO}_{2}$ with a Carlo Erba EA interfaced with a

157 Thermofinnigan Delta V configured in continuous flow mode. Samples were run in duplicate

158 with reproducibility of $0.2 \%$ and $<0.05 \mathrm{wt} \%$. Carbonate carbon isotope values $\left(\delta^{13} \mathrm{C}_{\text {carb }}\right)$ were

159 measured on a Dual Inlet VG Optima gas source mass spectrometer interfaced with an Isocarb

160 prep device. Reproducibility is roughly $0.1 \%$ and all carbon isotope data are normalized to a 161 VPDB scale.

\section{4.0 RESULTS AND DISCUSSION}

164 We used iron speciation chemistry, major element abundances, and stable carbon and 165 sulfur isotopic ratios to characterize oceanic redox conditions and biogeochemical cycling during 166 deposition of the Kel'tminskaya-1 succession (Fig. 2). The distribution of reactive iron minerals

167 in marine sediment has been calibrated in order to differentiate between oxic and anoxic water 168 column conditions (Canfield et al., 1996; Lyons et al., 2003; Poulton and Canfield, 2011;

169 Raiswell et al., 1988; Raiswell and Canfield, 1996; Raiswell et al., 1994; Raiswell et al., 2001).

170 In keeping with these calibrations, we interpret highly reactive iron $(\mathrm{FeHr}) /$ total iron $(\mathrm{FeT})>$ 
1710.38 as diagnostic of anoxia, with Phanerozoic and modern marine $\mathrm{FeHr} / \mathrm{FeT}$ values of

$1720.14 \pm 0.08$ and $0.26 \pm 0.08$ falling within a range characteristic of an oxic depositional

173 environment (Anderson and Raiswell, 2004; Poulton and Raiswell, 2002; Raiswell and Canfield,

174 1998). Fe/Al provides additional paleoredox information, with the added value of circumventing

175 dilution effects related to carbonate contents (Lyons et al., 2003). In the case of Fe/Al (here Fe

176 refers to FeT), crustal values of $\sim 0.5-0.6$ commonly characterize oxic conditions, with anoxia

177 generally giving rise to Fe/Al enrichments above this threshold (Lyons and Severmann, 2006).

178 We also report the chemical index of alteration (CIA) for siliciclastic samples in order to

179 monitor the nature and maturity of terrigenous fluxes into the basin (Nesbitt et al., 1997; Nesbitt

180 and Young, 1984; Nesbitt et al., 1996; Tosca et al., 2010). CIA, a measure of the degree of

181 weathering, is expressed as $\mathrm{Al}_{2} \mathrm{O}_{3} /\left[\mathrm{Al}_{2} \mathrm{O}_{3}+\mathrm{CaO}+\mathrm{Na}_{2} \mathrm{O}+\mathrm{K}_{2} \mathrm{O}\right]$. Given the importance of clay

182 minerals in organic matter burial and early diagenetic biogeochemistry (Hedges and Keil, 1995;

183 Keil et al., 1994; Rothman and Forney, 2007), we provide these data to assay potential changes

184 in source terrain for detrital siliciclastics that would in turn effect marine geochemical cycling,

185 all presented against the backdrop of previous work on the Neoproterozoic (Kennedy et al.,

186 2006; Tosca et al., 2010). Finally, reporting on the isotopic composition and abundances of

187 carbon and sulfur allows the geochemical measures described above to be linked more directly to

188 biogeochemical cycling. That is, the stoichiometry of heterotrophic remineralization reactions

189 provides a means of relating organic carbon (and factors associated with production, export and

190 burial) to electron accepting species within the Fe and $\mathrm{S}$ cycles (Fe-oxides and sulfate, in

191 particular). Below we discuss the distribution of these data in the context of their specific

192 geological setting, beginning with the oldest, Cryogenian-age samples. The full data are

193 presented in the supplemental materials. 


\subsection{Cryogenian records from the EEP}

Geochemical data for the carbonate-rich Cryogenian portion of the Kel'tminskya-1 197 drillhole mirror those of pre-Sturtian successions elsewhere (Canfield et al., 2008; Johnston et

198 al., 2010). Within the lower reach of the drillhole, $\delta^{13} \mathrm{C}_{\text {carb }}$ varies stratigraphically from $-4 \%$ o to $1994 \%$, consistent with earlier Neoproterozoic values from the Uralian Karatau Group (Podkovyrov

200 et al., 1998) and correlative carbonates on the Siberian Platform (Bartley et al., 2001). Organic

201 carbon content is generally low $(<0.4 \mathrm{wt} \%)$, and on average is higher in Cryogenian than in

202 younger intervals of the succession; $\delta^{13} C_{\text {org }}$ values for carbonate-rich Cryogenian samples vary

203 moderately around a mean of about $-29 \%$. A monotonic $\sim 8 \%$ o rise in $\delta^{13} \mathrm{C}_{\text {carb }}$ through the

204 Vapol' Formation may suggest an increase in organic carbon burial (Hayes et al., 1999), but a

205 tight, parallel change in $\delta^{13} \mathrm{C}_{\text {org }}$ is lacking. This lack of isotopic covariance is not uncommon in

206 Neoproterozoic carbonates (Fike et al., 2006; Swanson-Hysell et al., 2010), with recent work

207 pointing to complexities associated with $\delta^{13} \mathrm{C}_{\text {org }}$ as masking classic carbon isotope behavior

208 (Johnston et al., 2012; Knoll et al., 1986). In the case of the Cryogenian from Russia, the data

209 reported here support a stratigraphic link to the Ural Mountains and provide yet another example

210 of a pre-Sturtian carbon cycle with a large degree of variability. That is, the biogeochemical

211 picture provided by the Vapol' and Yskemess formations is consistent with those preserved 212 globally.

213 The Vapol' and Yskemess formations are carbonate dominated, with, on average, a 214 weight percent total iron (Fig. 2), much of which occurs as Fe-carbonate. The iron carbonate 215 fraction was determined via the first step of the normal Fe-speciation method, which is a weak 
216 acid extract defined to access carbonate phases (ankerite and siderite). The further application of

217 Fe-speciation data requires added discussion. It is important to appreciate that Fe-speciation

218 methods are calibrated on fine-grained siliciclastic sediments and the threshold values that guide

219 the reading of these metrics are similarly rooted. This, of course, complicates the direct and

220 literal interpretation of Fe-speciation data on carbonates. However, a number of points require

221 consideration. Foremost, the determination of iron carbonate, simply as a mass fraction and as

222 presented above, is robust. Next, the logic of Fe speciation methods is based on the precipitation

223 of Fe minerals under anoxic water column conditions and the subsequent settling of these

224 minerals, enriching local sediments. This iron enrichment is only possible when bottom water

225 conditions are anoxic. Thus, iron enrichment should occur in anoxic carbonate-rich

226 environments in the same fashion as it does in siliciclastic sediments, provided that there is a

227 reasonable amount of total $\mathrm{Fe}$ to source. Fe enrichment in carbonates can occur because of water

228 column Fe precipitation or suspended load siliciclastic admixture. (Fe/Al ratios for carbonates

229 were not measured due to interferences associated with high $\left[\mathrm{Ca}^{2+}\right]$, a function of carbonate

230 content.) Nonetheless, where FeT is high, as is the case with the EEP carbonates (FeT averages

$231 \sim 1.3 \mathrm{wt} \%$ ), the potential for minor Fe mobilization and redistribution following deposition

232 should not result in a spurious redox signal, and its association with carbonates suggests that it is

233 reactive iron as opposed to silicate iron or iron delivered with detrital fluxes. With the

234 discussion above and in noting that $\mathrm{Fe}$ in ancient carbonates usually stays close to original

235 depositional values (Tucker and Wright, 1990), Fe speciation has been successfully applied in a

236 variety of siliciclastic-poor settings (e.g. (Goldberg et al., 2005; Kendall et al., 2010; Marz et al.,

237 2008). However, although we argue that the Fe-speciation proxy should generally behave

238 similarly in carbonate-rich and siliciclastic rocks (also see (Poulton and Canfield, 2005)), we do 
239 not require the strict interpretation of carbonate iron data for the story forwarded here. We

240 simply present iron data from a limited Cyrogenian dataset against the backdrop of

241 contemporaneous siliciclastic units from North America, which is discussed below.

242 Iron speciation data for the Vapol' and Yskemess formations are variable but suggest a

243 highly reactive iron enrichment (and inferred bottom water anoxia), even though most of these

244 rocks were deposited in no more than a few tens of meters of water. Calculated $95 \%$ confidence

245 intervals for FeHr/FeT in the Vapol' and Yskemess are $0.54_{1.21}^{0.04}$ and $0.48_{0.79}^{0.12}$, respectively (see

246 also Fig. 2, 3). For the samples with elevated reactive iron contents, low sulfide contents (Fig. 2)

247 result in low $\mathrm{Fe}_{\mathrm{py}} / \mathrm{FeHr}$ ratios ( 0.1), which, coupled with an $\mathrm{Fe}$ speciation signal that is $\mathrm{Fe}_{\text {carb }}$

248 dominated (Figure 3), points to anoxic ferruginous water column conditions (Poulton et al.,

249 2004; Poulton and Canfield, 2011) for nearly 80\% of the Cryogenian samples. As noted above,

250 these data simply provide a complementary picture. Interestingly, however, and in support of

251 using Fe methods on carbonates, correlative successions from other continents also feature low

252 pyrite contents and signatures of anoxia. For example, by almost every metric, the EEP results

253 are consistent with the shale-dominated Chuar Group in the Grand Canyon, USA (Johnston et

254 al., 2010). There, a stratigraphically resolved data-set records persistent subsurface water

255 column anoxia, in waters of similar depth, with only modest sulfide production corresponding to

256 intervals of increased TOC burial. Given the dominant role of the atmosphere (and the $\mathrm{O}_{2}$

257 reservoir) in disseminating oxygen into the surface mixed layer of the ocean, anoxia on the shelf

258 likely reflects lower $\mathrm{O}_{2}$, noting that local biogeochemistry can influence the DO load (Johnston

259 et al., 2010). 


\subsection{Ediacaran records from the EEP}

Geochemical data from the siliciclastic Ediacaran portion of the Kel'tminskya-1 drillhole

263 (above $2779 \mathrm{~m}$ ) suggest a more fully oxygenated water column, as well as an increasing trend

264 toward redox stability moving upward through the section. Total iron abundances for the

265 Vychegda, Redkino and Kotlin formations are significantly higher than for the carbonate-rich

266 Cryogenian section, as expected for a shale-dominated succession, with $\mathrm{Fe}$ and $\mathrm{P}$ concentrations

267 similar to average Phanerozoic shale contents ( $\sim 5 \mathrm{wt} \%$ and 0.07 wt $\%$, respectively; Fig. 2)

268 (Turekian and Wedepohl, 1961). The distribution of reactive iron phases from the EEP suggests

269 a markedly more oxygenated depositional environment for the Ediacaran shales than for the

270 underlying Cryogenian deposits. Ediacaran $\mathrm{FeHr} / \mathrm{FeT}$ values oscillate around a mean of $0.26_{0.36}^{0.13}$

271 (95\% confidence interval), similar to that characteristic of modern oxic marine sediments (Fig. 2,

272 3) (Poulton and Canfield, 2011; Poulton and Raiswell, 2002).

273 Although suggesting more oxygenated conditions, in detail the chemical variability in the

274 Vychegda Formation does allow (and may indicate; (Poulton and Canfield, 2011)) recurring

275 intervals of less oxygenated bottom waters, which were replaced by more persistently

276 oxygenated conditions by Redkino time. Along those lines, a closer look at the data reveals an

277 important change within the Ediacaran portion of the succession. Notably, the Vychegda-

278 Redkino sequence boundary separates distinct geochemical regimes (Fig. 2). Thus, we subdivide

279 the Ediacaran stratigraphy into the earlier Ediacaran interval ( 580 to $558 \mathrm{Ma})$ represented by

280 the Vychegda Formation above $2779 \mathrm{~m}$ and the upper Ediacaran interval ( 558 to $542 \mathrm{Ma}$ )

281 recorded by the Redkino-Kotlin formations. As depicted in Figure 3, many of the reported

282 geochemical metrics from the early and late Ediacaran successions scatter around similar average

283 values, but early Ediacaran samples consistently show more variability. Our data, thus, present a 
284 picture of a shelf environment that gradually evolved from one of significant redox heterogeneity

285 in the Cryogenian, through a more oxygenated but still unstable redox regime in the early

286 Ediacaran, to a stable, persistently oxygenated state in the late Ediacaran.

In the context of this interpretation, we can consider implications for local

288 biogeochemical cycling. As posited earlier, atmospheric oxygen is one of a few levers on

289 bottom water chemistry, acknowledging that heterotrophy following TOC loading and the

290 ensuing benthic fluxes represent a significant local sink for oxidants (Johnston et al., 2010). To

291 evaluate these contrasting mechanisms, we investigate the relationship between the carbon,

292 phosphorus and iron budgets inferred from Kel'tminskaya-1 samples. The EEP shale is

293 generally TOC lean (Fig. 2, 5), contains typical P contents, and low overall pyrite concentrations.

294 The low observed pyrite contents suggest that dissimilatory sulfate reduction (Canfield, 2001)

295 was not a prominent remineralization pathway in these settings. Without sulfate, this leaves

296 oxygen, nitrate and iron oxides as potentially prominent electron acceptors. The ratio of TOC to

297 reactive iron does not reveal a significant linkage (Fig. 5); however, the conversion of originally

298 mixed valence Fe inputs to predominantly ferrous iron carbonate does require a reductive

299 catalyst, which most naturally would be dissimilatory iron reduction (Fig. 5a). As an extension,

300 the efficiency of $\mathrm{P}$ burial relative to organic $\mathrm{C}$ can provide important information about

301 preferential $\mathrm{P}$ regeneration through remineralization reactions under different redox conditions

302 (Algeo and Ingall, 2007; Ingall and Jahnke, 1994). This often results in a strong positive

303 correlation between $\mathrm{C}$ and $\mathrm{P}$, and high organic C:P under anoxic conditions (cf. (Jilbert et al.,

304 2011; Kraal et al., 2010). For example, organic C:P in modern anoxic settings can exceed 300,

305 but deposition under fully oxygenated modern conditions often drive organic C:P below 50

306 (Algeo and Ingall, 2007). In the case of the EEP, organic C:P ratios are consistently low, 
307 approaching 1:1 for the Vychegda and $~ 2: 1$ for the Redkino and Kotlin formations (Fig. 5b).

308 Low organic C:P ratios, coupled with low total organic $\mathrm{C}$ and the lack of an authigenic P

309 enrichment above that of normal marine shale, is often interpreted as a result of a higher redox

310 potential in the local environment, consistent with an oxygenated water column (Algeo and

311 Ingall, 2007).

The distinction between early and late Ediacaran geochemistry can be investigated more

313 quantitatively. To explore the robustness of this partitioning, we bootstrapped a Monte Carlo

314 resampling $(n=1000)$ of the Vychegda - Redkino/Kotlin data sets $(n=35$ and 44, respectively).

315 This approach clearly identifies differences in Fe/Al ratios and pyrite $\delta^{34} \mathrm{~S}$ values, with CIA

316 values holding steady near a value of 0.70 (Fig. 6). Interestingly, the average FeHr/FeT value

317 differs little between lower Ediacaran Vychegda shales and those of the overlying Redkino-

318 Kotlin succession (Fig. 6a); however, the upper and lower Ediacaran successions differ in the

319 distribution of $\mathrm{FeHr} / \mathrm{FeT}$ values about the mean, indicating a marked stabilization of the redox

320 environment by the late Ediacaran. Whereas the earlier Ediacaran samples record highly

321 variable bottom water conditions, younger Ediacaran shales document a stable and persistently

322 oxic seafloor. This up-section change in FeHr/FeT distribution does not necessarily require an

323 increase in the dissolved oxygen content of seawater, although increasing oxygen provides a

324 ready mechanism for increased redox stability. Fe/Al values also closely track this shift (Fig. 6),

325 and in the absence of apparent change in other possible controls on FeT, these data point toward

326 a broadly oxygenated environment throughout the entire interval of the Ediacaran Period

327 sampled by the drillcore (cf. (Lyons and Severmann, 2006; Lyons et al., 2003; Severmann et al.,

328 2008)). Similarly, more variability in Fe/Al ratios in the early Ediacaran, in part perhaps related

329 to FeT, reflects a greater degree of redox instability, which is again succeeded by stable and 
330 oxic-like Fe/Al ratios in the younger Ediacaran part of the succession. Finally, the CIA values of

331 these two populations are similar (Fig. 5), and thus the chemical maturity of terrigenous clay

332 inputs can also be taken as roughly constant, ruling out major change in the terrestrial weathering

333 regime as a driver of the observed geochemical stabilization (Kennedy et al., 2006; Tosca et al.,

334 2010). As clay minerals provide a critical template for the proficient burial of organic matter, it

335 is important to place constraints on this vector. This is especially true considering that the

336 inception of pedogenic clay formation was proposed as a spur for Ediacaran changes in organic

337 burial and associated oxygen production (Kennedy et al., 2006). The absence of a change in the

338 chemical composition of weathered material and sedimentation rate (as reflected by a persistent

339 and similar depositional setting) indicates that there was no major change in provenance or

340 composition of sediments entering the EEP basin.

341 Our data thus indicate that by the time that the main Vychegda sequence began to

342 deposit, marine redox conditions had changed from persistent anoxia to a broadly oxygenated

343 water column. This conclusion, of course, reflects oceanographic conditions in a single basin

344 and does not preclude earlier oxygenation of water masses elsewhere. That noted, data from

345 other continents similarly record a redox transition within the lower part of the Ediacaran Period

346 (Canfield et al., 2007; Fike et al., 2006; Scott et al., 2008; Shen et al., 2008). Where the EEP

347 data extend our understanding is their recording of redox stabilization, perhaps at ca. 560 Ma.

348 Neither redox transition nor redox stabilization require that $p \mathrm{O}_{2}$ reached modern levels in the

349 Ediacaran - indeed, both data and models suggest that present day $\mathrm{pO}_{2}$ was first reached only in

350 the later Paleozoic Era (Bergman et al., 2004; Berner and Canfield, 1989; Dahl et al., 2010).

351 Rather they suggest that, perhaps for the first time in Earth history, oxygen levels were sufficient

352 to limit the spread of anoxia in shallow water settings. 


\section{$354 \quad 4.3$ Insight from the sulfur cycle}

The sulfur cycle is sensitive to the oxygen content of the atmosphere, and as such, may

356 provide a test of proposed mid-Ediacaran transitions (cf. (Berner and Canfield, 1989; Claypool et

357 al., 1980; Garrels and Lerman, 1981)). We first look at the limited data from the Cryogenian

358 Vapol' and Yskemess formations. Here, $\delta^{34} \mathrm{~S}$ values are highly variable and range from above

359 estimates of contemporaneous seawater sulfate (Johnston et al., 2010) to almost -30\%o. Scaling

360 loosely with TOC content (Fig. 7b), the 50\%o range certainly reflects primary microbial

361 contributions from sulfate reduction and may also indicate sulfur disproportionation reactions

362 (Canfield and Teske, 1996; Johnston et al., 2005), although mass-balance effects of local sulfate

363 limitation might also have been in play (Canfield, 2001; Hayes, 2001). Although the data

364 exhibit some scatter, in particular where TOC values are higher, $\delta^{34} \mathrm{~S}$ values are generally more

365 enriched, consistent with sulfate limitation within the sediments and, consequently, near-

366 quantitative reduction of pore-water sulfate.

367 The sulfur isotopic composition of pyrite from the Ediacaran portion of the EEP is also

368 quite variable. The $\delta^{34} \mathrm{~S}$ values of pyrite within the Vychegda Formation are, on average, more

369 depleted and variable than sulfides from the overlying Redkino and Kotlin formations (a mean

370 value of $2 \%$ as opposed to $12 \%$ or for the late Ediacaran; Fig. 6d). Importantly, the Vychegda

371 Formation is also more pyrite-rich than overlying strata, averaging $\sim 0.08$ and ranging up to 0.3

$372 \mathrm{wt} \%$ pyrite (the Redkino and Kotlin formations average $\sim 0.02 \mathrm{wt} \%$ ). If we presume a $\delta^{34} \mathrm{~S}$ of

373 seawater sulfate between $20 \%$ and $30 \%$, similar to estimates from early Ediacaran successions

374 in Oman, Namibia, South China and Australia (Fike et al., 2006; Halverson and Hurtgen, 2007; 
375 Hurtgen et al., 2002; Hurtgen et al., 2006; McFadden et al., 2008), then the net fractionation

376 associated with a consortium of microbial metabolisms only requires the influence of sulfate

377 reduction. If the Ediacaran seafloor was moving toward a more oxygenated state, as suggested

378 by iron speciation data, then an oxidative sulfur cycle was almost certainly present in the water

379 column. Emerging tools, specifically the minor sulfur isotopes (Johnston, 2011), may provide a

380 test of this interpretation and allow for the isotopic contributions of reductive and oxidative 381 processes to be more uniquely constrained.

383 sulfur isotope compositions that cluster toward more enriched values. Although not as enriched

384 as the super-heavy pyrites observed elsewhere (Ries et al., 2009), values are almost always

385 positive (> 0\%o). Limited data (Fike and Grotzinger, 2008; Fike et al., 2006; Kampschulte and

386 Strauss, 2004) and a model treatment of that data (Halverson and Hurtgen, 2007) suggest an

387 enrichment in the $\delta^{34} \mathrm{~S}$ of seawater sulfate toward the end of the Ediacaran, although more recent

388 datasets suggest seawater sulfate remained near $20 \%$ at that time (Ries et al., 2009). The lack of

389 consistency among these data is curious, as it points to either the infidelity of certain proxies,

390 poor absolute correlation between continents, or - perhaps most likely - a heterogeneous

391 seawater sulfate reservoir. Regardless of the reason, this variability makes the diagnosis of the

392 Redkino and Kotlin sulfur cycle difficult. If sulfate was becoming more ${ }^{34} \mathrm{~S}$ enriched at that

393 time, then the net fractionation between sulfate and sulfide may not have changed significantly

394 from that observed in the underlying Vychegda Formation. However, if sulfate remained largely

395 invariant, these data suggest that the net fractionation decreased drastically. This later scenario

396 could reflect an extreme deficiency in seawater sulfate concentrations (Habicht et al., 2002), but

397 is more likely associated with simple sulfate limitation within the sediments. The latter 
398 interpretation is consistent with other geochemical proxies in suggesting that, regionally, anoxia

399 developed only within the sediment column.

\subsection{Incorporating biological considerations}

403 (Cryogenian) portion recording the common occurrence of ferruginous water masses in shallow-

404 water environments; a lower Ediacaran succession documenting more oxygenated, but still

405 fluctuating bottom-water conditions on the shelf, and an upper Ediacaran interval that records a

406 fully and persistently oxic water column. Fossils divide regional stratigraphy in much the same

407 fashion (Fig. 1, 2): the Cryogenian rocks are characterized by a modest diversity of protists

408 (Vorob'eva et al., 2009a), recording microscopic eukaryotes that could thrive at low $p \mathrm{O}_{2}$. In

409 contrast, the upper Ediacaran (Redkino-Kotlin) succession contains macroscopic animals, as well

410 as trace fossils (Fedonkin et al., 2007; Fedonkin and Waggoner, 1997). In between lie the

411 diverse, large ornamented microfossil assemblage characteristic of lower Ediacaran successions

412 worldwide (Vorob'eva et al., 2009a). Data on morphology, wall ultrastructure, size frequency

413 distribution and preserved intracellular contents suggest that many of these distinctive

414 microfossils represent egg and diapause cysts of early animals (Cohen et al., 2009; Sergeev et al.,

415 2011; Yin et al., 2007). Modern animals produce resting stages when fertilized eggs have a high

416 probability of landing where growth is difficult or impossible (Cohen et al., 2009); therefore, it

417 makes physiological sense that the Ediacaran cysts should be abundant and diverse in basins

418 where geochemical data indicate bottom water redox instability. Whether animal or something

419 else, the abundance of these cysts in Vychegda Formation shale indicates that environmental 
420 conditions were frequently inimical to growth. Few if any of these microfossils persist into beds

421 marked by persistently oxic water column conditions. The hypothesis that the early Ediacaran

422 seafloor was intermediate in redox character to its pre-Ediacaran and late Ediacaran counterparts

423 is also consistent with the presence of moderately differentiated but essentially two-dimensional

424 macrofossils in earlier Ediacaran shales from China (Yuan et al., 2011).

425 Diverse macroscopic animals first appear regionally in Redkino-aged deposits (Sokolov

426 and Fedonkin, 1990; Sokolov and Iwanowski, 1990). Many of these appear to have a simple

427 anatomy, and may largely represent bodyplans in which upper and lower epidermis enclose inert,

428 mesoglea-like material (e.g., (Sperling and Vinther, 2010)). One body-fossil population,

429 however, is widely regarded as the remains of a bilaterian animal. Kimberella quadrata was a

430 roughly $2 \mathrm{~cm}$ long and at least $1 \mathrm{~cm}$ thick organism whose fossil impressions show a distinct

431 anterior-posterior axis with a plane of symmetry running from front to back (Fedonkin et al.,

432 2007). It is occasionally preserved at the end of a trace fossil that documents directional

433 movement across the sediment surface and sometimes also occurs with anterior scratch marks

434 similar to those made by the radulae of mollusks during feeding (Fedonkin et al., 2007). While

435 the precise phylogenetic relationships of Kimberella remain open to question, it has a strong

436 claim to status as a bilaterian animal and almost undoubtedly would have required more oxygen

437 for physiological function than other commonly preserved Ediacaran macroorganisms.

438 Independently of Kimberella, and consistent with the predictions of molecular clocks (Erwin et

439 al., 2011), trace fossils in the Redkino succession indicate a modest diversity of bilaterian

440 animals. Thus, in the EEP, geochemical evidence for stabilization of pervasively oxic conditions

441 in shelf environments correlates with the appearance of animals with unprecedentedly high

442 oxygen demand. 
The statistical treatment presented in Figure 6 helps further explain why the Vychegda

444 and Redkino/Kotlin intervals should be characterized by life cycles with resting stages and large,

445 highly energetic animals, respectively. While neither succession displays Fe-speciation evidence

446 for strong water mass anoxia, and while the mean value of $\mathrm{FeHr} / \mathrm{FeT}$ is similar for the two

447 intervals, the greater dispersal about the mean for Vychegda samples results in nearly half of all

448 values falling within the 'equivocal' redox range; Redkino/Kotlin samples do not record such a

449 FeHr enrichment. In a recent review, it has been postulated that these intermediate $\mathrm{FeHr} / \mathrm{FeT}$

450 values (from 0.26-0.38 in FeHr/FeT) point toward "possible anoxia" (Poulton and Canfield,

451 2011). The term "dysoxia" is commonly frowned upon by geochemists because conditions of

452 low (but measurable) DO are not demarcated by a reliable geochemical fence. Biologists, in

453 contrast, pay close attention to dysoxic/hypoxic waters because their low oxygen contents (less

454 than 1-2 ml/l) strictly limit animal size, locomotion and diversity (e.g., (Diaz and Rosenberg,

455 1995; Seibel and Drazen, 2007; Vaquer-Sunyer and Duarte, 2008)). Hypoxia during the

456 deposition of the Vychegda Formation may have been sufficiently frequent to favor small

457 animals able to survive episodic bottom water anoxia as well as other unfavorable conditions by

458 forming resting cysts. The removal of this limitation, then, correlates with the first appearance of 459 large, thick, highly motile animals.

461 fully consistent with the hypothesis that evolving redox conditions exerted a strong influence on

462 the timing of early animal evolution. What about contrasting ecological hypotheses? Few would

463 dispute that ecology played an important role in animal diversification (Butterfield, 2007; Knoll,

464 1994), but what geochemical and paleontological features are uniquely predicted by this

465 hypothesis? The ornamentation of large Ediacaran microfossils have been interpreted as a 
466 defensive response to bilaterian predators (Peterson and Butterfield, 2005), but no bilaterian

467 macrofossils have been found in Russian or other rocks that contain these ornamented

468 microfossils, and as bilaterians begin to populate the fossil record, the microfossils largely

469 disappear. Geochemically, ecological reorganization in a physiochemically stable ocean should

470 be reflected in changes in biogeochemical cycling across the Vychegda-Redkino boundary

471 (Butterfield, 2009; Logan et al., 1995). For instance, changes in the articulation of the biological

472 pump (Butterfield, 2009) would carry direct consequences for carbon export, organic matter

473 burial and preservation, and possibly even the type of organic compounds preserved in the

474 sediments. As recorded on the EEP, however, neither TOC nor $\delta^{13} \mathrm{C}_{\text {org }}$ values change

475 significantly across this boundary; nor do pyrite contents or S:C ratios. The sulfur isotopic

476 composition of pyrite does record mid-Ediacaran change (Fig. 2, 6, 7), and, like other proxies,

477 records much less variability in the later Ediacaran. The more positive $\delta^{34} \mathrm{~S}$ values found for

478 younger Ediacaran pyrites may simply be another consequence of redox evolution, as sulfate

479 reduction increasingly became restricted to lower and lower horizons within the sediment

480 column, which could have facilitated the net quantitative reduction of pore-water sulfate. The

481 fossil record indicates that evolving animals drove ecological change, especially in the

482 Cambrian, when diverse new bodyplans populated the oceans (Bengston and Morris, 1992);

483 however, available data provide little support for Ediacaran ecological reorganization outside of

484 the context of changing physiochemical conditions. 
Geochemical reconstructions of Cryogenian and Ediacaran successions on the margin of

488 the Eastern European Platform preserve a history of Earth surface evolution that can be related to 489 similar reconstructions from other continents (Canfield et al., 2007; Johnston et al., 2010;

490 McFadden et al., 2008; Shen et al., 2008), and, more importantly, extends our understanding of

491 how atmospheric oxygen may have influenced the early diversification of metazoans. Previous

492 geochemical models have qualitatively linked proposed increase in the dissolved oxygen content

493 of the ocean with the appearance of macroscopic animals, and although tight constraints on

494 absolute $\mathrm{pO}_{2}$ remains elusive, data from the EEP suggests that the redox stabilization of the local

495 marine depositional environment may be equally important. This does not preclude a role for

496 changing $\mathrm{pO}_{2}$ as a means of driving stabilization, although any such mid-Ediacaran change could

497 have been quite modest. A better understanding of absolute $\mathrm{pO}_{2}$ trajectory may be possible

498 through high-resolution reconstructions of marine depositional environments with high TOC

499 loading (for instance, the Ediacaran successions of the Wernecke and Mackenzie Mountains in

500 the Yukon, Canada), which in contrast to the EEP, would provide a more prominent oxidant sink

501 in the bottom waters and further insight into biogeochemical cycling.

In the Kel'tminskaya-1 drillhole, unconformities separate three paleontologically and 503 geochemically defined packages, limiting inferences about the timing, rate, and mechanisms

504 underlying these redox state transitions. That noted, the paleontological progression recorded in

505 northern Russia characterizes Neoproterozoic successions observed globally. The oldest 506 macroscopic animals occur in 565-579 Ma strata from Newfoundland (Narbonne, 2005), a deep-

507 water succession that records a stably oxic seafloor (Canfield et al., 2007) predating Redkino 508 deposition by up to 20 million years. Quite possibly, the fossiliferous Newfoundland rocks 509 record a time interval missing on the EEP along the Vychegda-Redkino sequence boundary. It is 
510 also possible, however, that redox stability was not imposed synchronously across the globe

511 (Kah and Bartley, 2011). Indeed, protracted Ediacaran increases in $p \mathrm{O}_{2}$ might have oxygenated

512 basins regionally, one after another, with biological changes following suit as environmental

513 conditions allowed. This hypothesis can be tested by integrated sequence stratigraphic,

514 paleontological, geochemical, and geochronological analyses of Ediacaran successions.

515 By themselves, however, paleontological and geochemical data from the northeastern

516 EEP support two first-order conclusions. First, as evidenced by a growing body of $\mathrm{FeHr} / \mathrm{FeT}$

517 data, the oft-cited Neoproterozoic 'oxygenation' does not appear to be associated with the

518 Shuram anomaly, as iron speciation data suggests an earlier arrival of this oxidizing capacity and

519 cannot speak to the rate of change (gradual versus abrupt). Continued study of Cryogenian

520 records will help to identify and describe the anatomy of this oxygenation, were a profound

521 change in atmospheric chemistry to exist. Whatever the answer, the participation of oxygen in

522 the atmospheric carbon cycle (as it interacts with critical greenhouse gasses, namely $\mathrm{CO}_{2}$ and

$\left.523 \mathrm{CH}_{4}\right)$ suggests a relationship between Neoproterozoic $p \mathrm{O}_{2}$ and low-latitude Cryogenian

524 glaciations (Hoffman et al., 1998). Second, and most important for biological records, by about

525 580-560 Ma, redox stability came to define shallow marine seafloor environments, possibly (but

526 not necessarily) reflecting a further increase in $p \mathrm{O}_{2}$. Our data thus most closely support the

527 classic hypothesis that increasing atmospheric oxygen paved the way for the global expansion of

528 bilaterian macrofossils, but underscores the role of redox stability in potentiating end-Proterozoic 529 evolutionary events. 
531 Acknowledgements: We appreciate early and ongoing discussions with P. Cohen, N. Tosca, B.

532 Gill and E. Sperling. D. Schrag and G. Eischeid are thanked for laboratory assistance. This

533 work was funded by the Harvard Microbial Sciences Initiative (DTJ), NASA Exobiology (DTJ,

534 AHK) and the Astrobiology Institute, MIT node (DJ and AHK), NERC (SWP), RBBR grant 10535 05-00294 (VNS and NGV), and NSERC Discovery (AB). 
536 Figure 1: A map of the Timan Ridge area showing the location of the Kel'tminskaya-1 drillhole

537 on the northeastern margin of the Eastern European Platform (see arrow on the inset for the

538 location on the Eastern European Platform). At right, a cartoon timeline of the characteristic

539 fossils found in Cryogenian and Ediacaran rocks; protistan assemblages (Porter et al., 2003) are

540 replaced by large ornamented microfossils, which gave way to complex animals (e.g.

541 Kimberella).

542
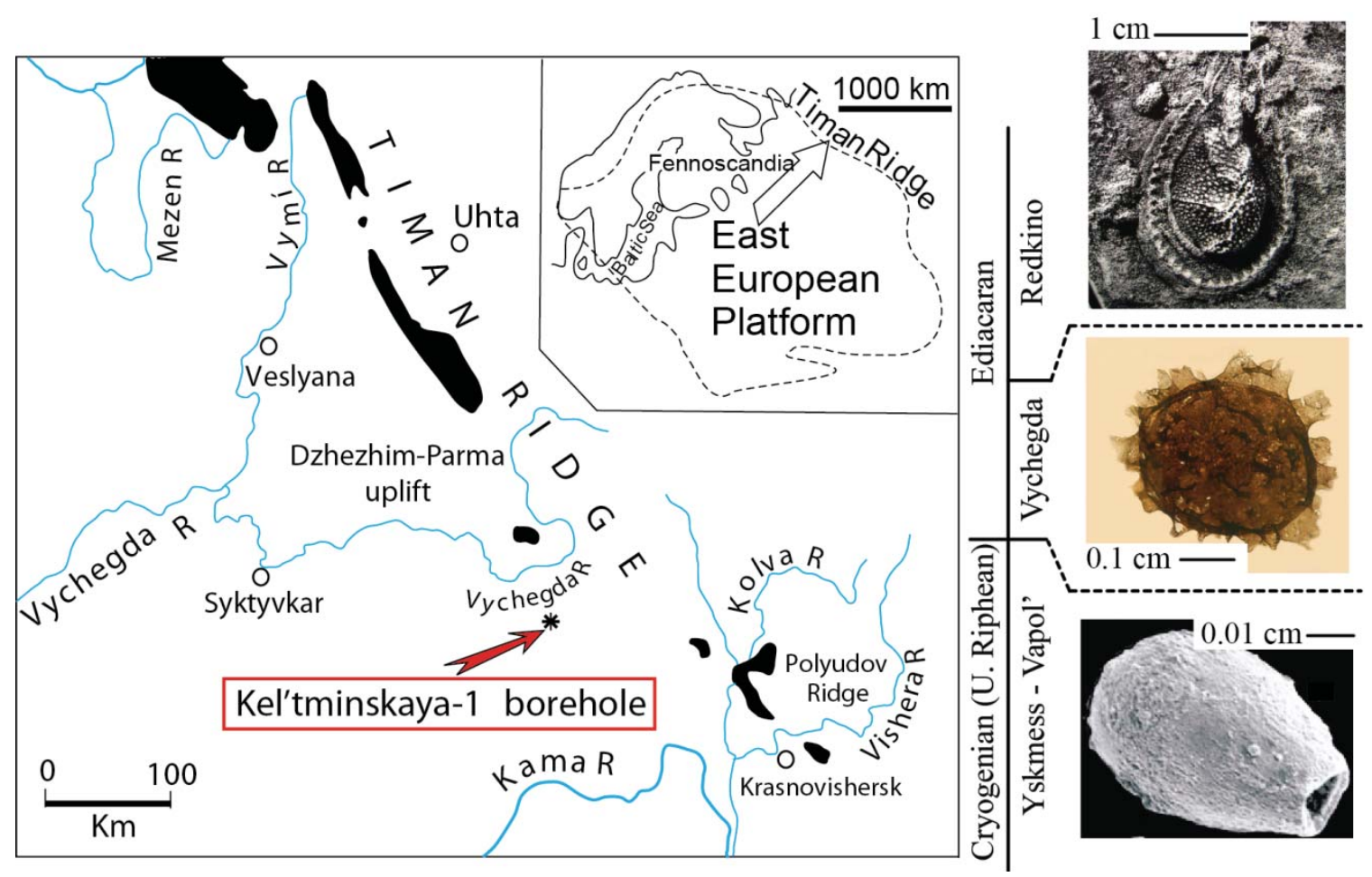
543 Figure 2: Stratigraphic redox proxy variations for the Kel'tminskaya-1 drillhole. Note the break

544 in vertical scale at the Vapol'-Vychegda sequence boundary. The age of deposition is based on

545 lithological and biostratigraphic correlation to the White Sea and Ural Mountains successions.

546 Note that the $635 \mathrm{Ma}$ age relates to the strata underlying the hiatus in the lower Vychegda,

547 whereas the $\sim 580 \mathrm{Ma}$ age relates to that of the overlying ECAP-containing portion of the unit.

548 All methods and additional data are described in the text and presented in the supplemental

549 materials. The two leftmost chemostratigraphic frames are on a log scale. Vertical lines in the

$550 \mathrm{FeHr} / \mathrm{FeT}$ column are discussed in the text, with red circles with lines extending horizontally

551 representing samples with $\mathrm{FeHr} / \mathrm{FeT}>0.6$ and indicate anoxia. Where indicating anoxia, all

552 samples are ferruginous. Carbon isotope axes for carbonate and organic carbon (far right panel)

553 are offset by $31 \%$.

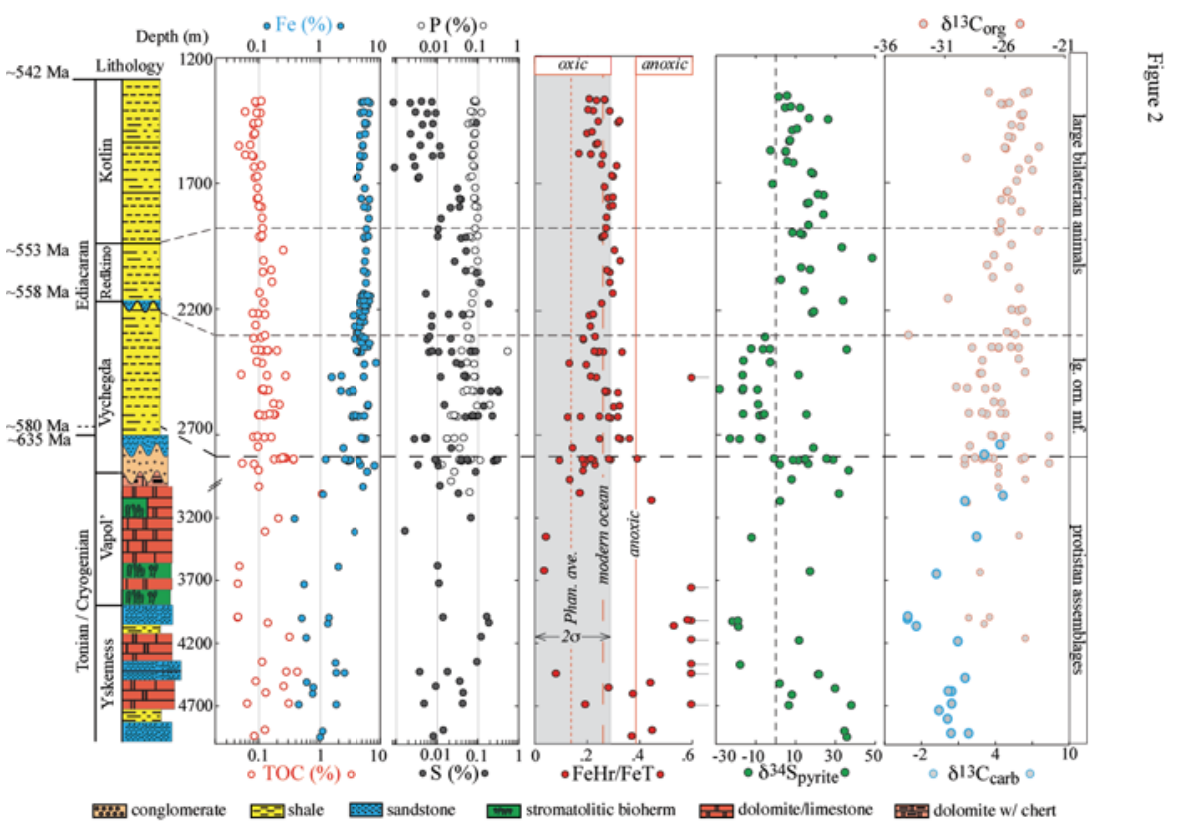


555 Figure 3: Two frames indicating the relationship between FeHr/FeT (a measure of anoxia)

556 versus (a) top: a quantification of pyrite iron, $\mathrm{Fe}_{\mathrm{py}} / \mathrm{FeHr}$ and (b) bottom: an alternative means of

557 recording anoxia. A key to the symbols is listed under the figure, with all data coming from this

558 work. In (a), regions of the plot characteristic of particular water column redox state and

559 chemistry are noted. That is, $\mathrm{FeHr} / \mathrm{FeT}>0.38$ is indicative of anoxia, whereas values below the

560 modern average (0.26) are indicative of oxic conditions (Anderson and Raiswell, 2004; Poulton

561 and Canfield, 2011; Poulton and Raiswell, 2002; Raiswell and Canfield, 1998). The hashed

562 region, between these two values, carries a more equivocal meaning. For reference, the

563 Phanerozoic average for shale is also listed (dashed line). In frame (b), the crustal average of

$564 \mathrm{Fe} / \mathrm{Al}$ is indicated. See text for further discussions, especially that of the Vapol' and Yskemess

565 formation carbonates.
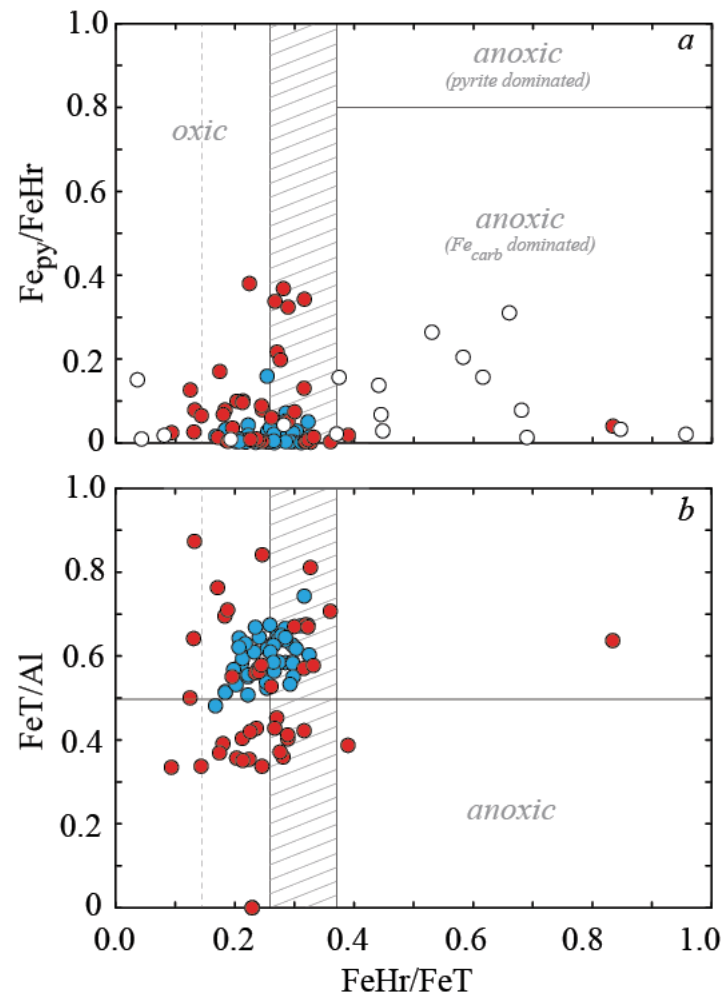

○ Vapol' and Yskemess fms. Vychegda Fm. - Redkino and Kotlin fms. 
567 Figure 4: A summary of Fe-speciation data for pre-Sturtian sediments from Russia (this work),

568 North America (Johnston et al., 2010), East Greenland, and Australia (Canfield et al., 2008).

569 Axes are the same as Figure 3a, as are distinctions in $\mathrm{FeHr} / \mathrm{FeT}$.

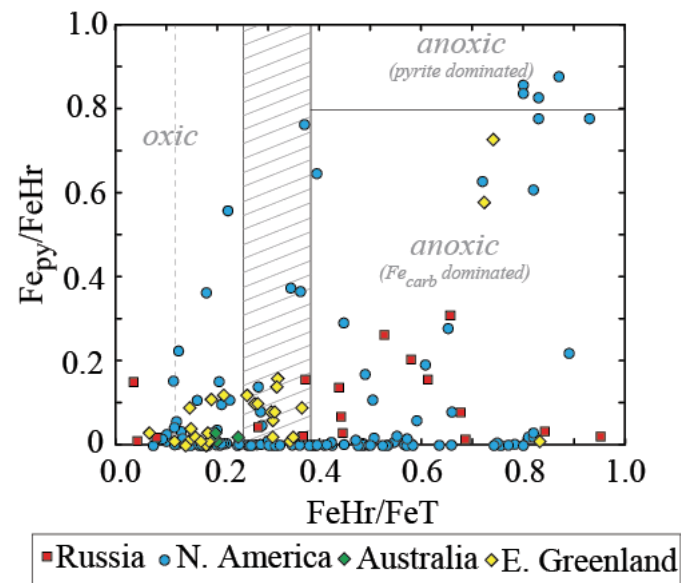

571 Figure 5: An analysis of the covariance between different biogeochemical metrics. Here, we

572 examine changes in TOC against (a) reactive iron to total iron ratios, and (b) versus total $\mathrm{P}$

573 content. Both figures are also contoured by lines representing different ratios between the 574 abscissa and ordinate measures. These features are fully described in the text and both relate to 575 oxygen content of the local environment.
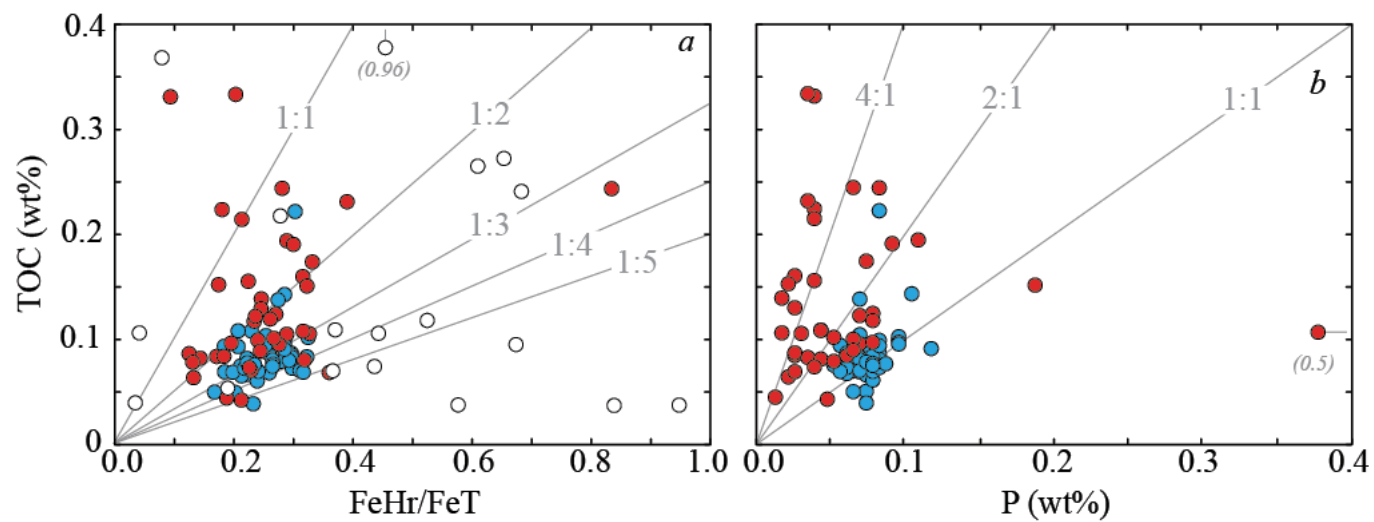

$\circ$ Vapol' and Yskemess fms. - Vychegda Fm. ○ Redkino and Kotlin fms. 
577 Figure 6: A statistical resampling of key geochemical metrics from the Ediacaran of the EEP.

578 Data sets were divided at the Vychegda-Redkino sequence boundary (Vychegda in blue,

579 Redkino and Kotlin in red). Importantly, sampling of the Vychegda began at $2779 \mathrm{~m}$, the bed at

580 which distinctly Ediacaran acritarchs first appear (Vorob'eva et al., 2009a). a) A measure of

581 overall water column redox, $\mathrm{FeHr} / \mathrm{FeT}$. b) The relationship between $\mathrm{Fe}$ and Al. c) The chemical

582 index of alteration is described in the text. d) The isotopic composition of pyrite sulfur. In all

583 cases, one thousand synthetic runs were performed (binned and recorded on ordinate axis).

584 Ordinate axis scale changes from frame to frame.

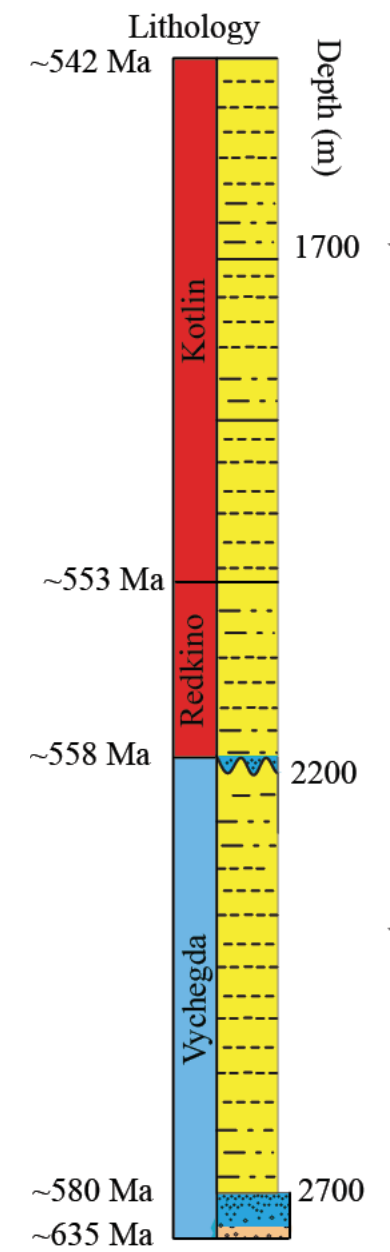

585
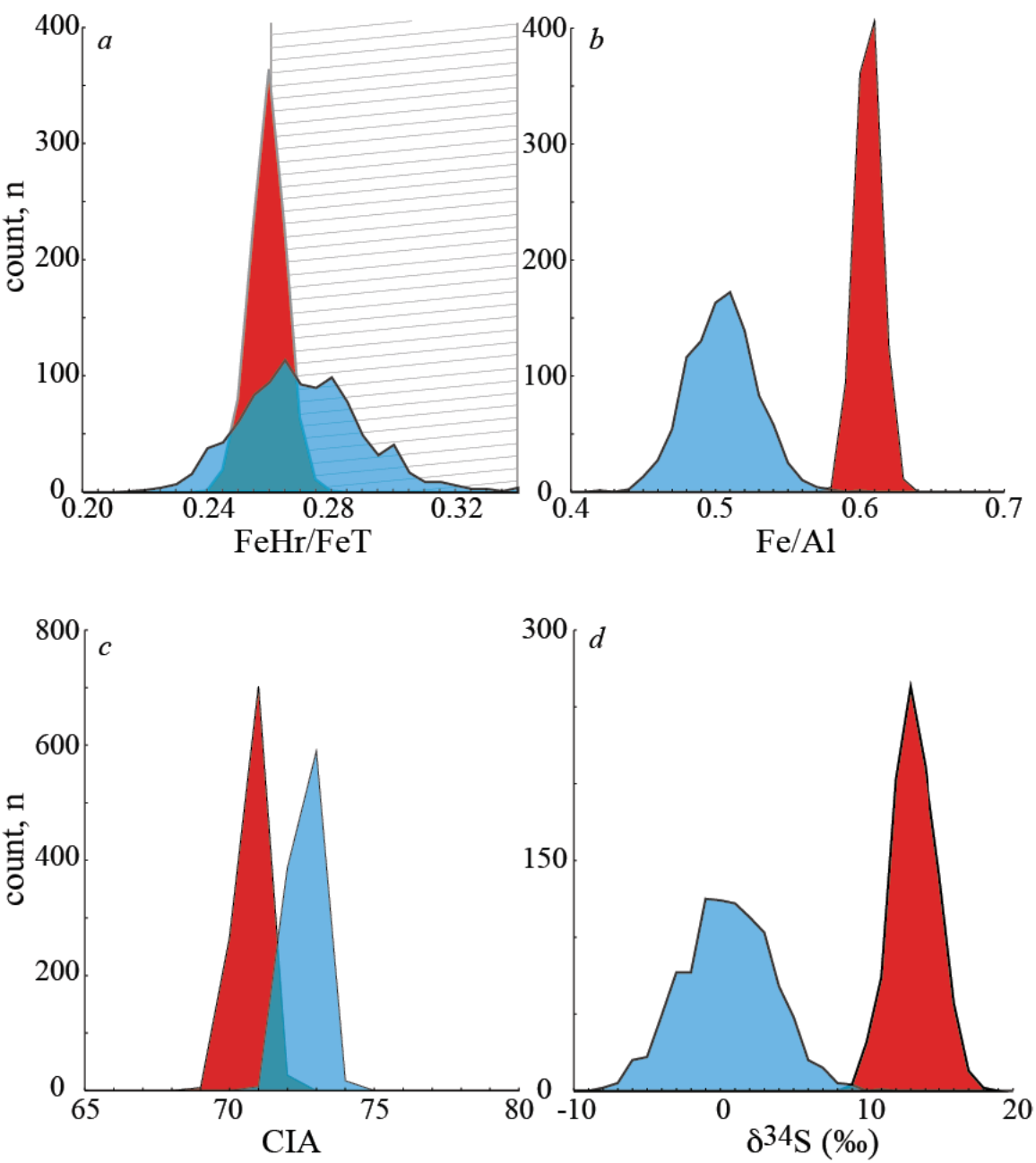
586 Figure 7: Two plots examining the relationship between the sulfur isotopic composition of 587 pyrite and (a) reactive to total iron ratio $(\mathrm{FeHr} / \mathrm{FeT})$ and (b) total organic carbon content, TOC. 588 Symbols are described below the figure, and the data is discussed in the text.

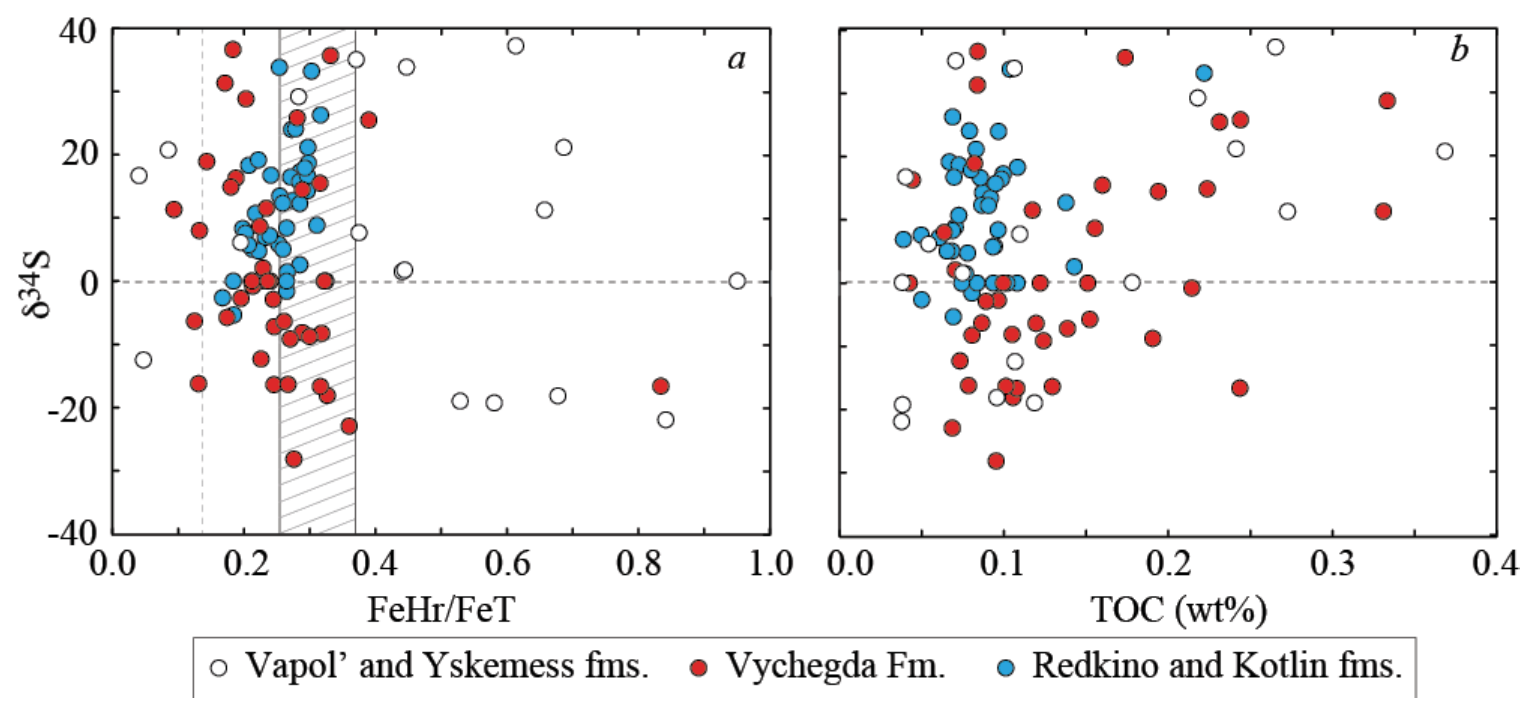


REFERENCE LIST:

591 Algeo, T.J., Ingall, E., 2007. Sedimentary Corg: P ratios, paleocean ventilation, and

592 Phanerozoic atmospheric $\mathrm{pO}_{2}$. Palaeogeography Palaeoclimatology Palaeoecology 256, $593 \quad 130-155$.

594 Anderson, T.F., Raiswell, R., 2004. Sources and mechanisms for the enrichment of highly 595 reactive iron in euxinic Black Sea sediments. American Journal of Science 304, 203-233.

596 Bartley, J.K., Semikhatov, M.A., Kaufman, A.J., Knoll, A.H., Pope, M.C., Jacobsen, S.B., 2001.

597 Global events across the Mesoproterozoic-Neoproterozoic boundary: C and Sr isotopic 598 evidence from Siberia. Precambrian Research 111, 165-202.

599 Bengston, S., Morris, S.C., 1992. Early radiation of biomineralizing phyla. Topics in 600 Geobiology 10, 447-481.

601 Bergman, N.M., Lenton, T.M., Watson, A.J., 2004. COPSE: A new model of biogeochemical 602 cycling over Phanerozoic time. American Journal of Science 304, 397-437.

603 Berner, R.A., Canfield, D.E., 1989. A new model for atmospheric oxygen over Phanerozoic 604 time. American Journal of Science 289, 333-361.

605 Bingen, B., Griffin, W.L., Torsvik, T.H., Saeed, A., 2005. Timing of Late Neoproterozoic 606 glaciation on Baltica constrained by detrital zircon geochronology in the Hedmark Group, 607 south-east Norway. Terra Nova 17, 250-258.

608 Butterfield, N.J., 2007. Macroevolution and macroecology through deep time. Palaeontology $60950,41-55$.

610 Butterfield, N.J., 2009. Oxygen, animals and oceanic ventilation: an alternative view. 611 Geobiology 7, 1-7. 
612 Canfield, D.E., 2001. Biogeochemistry of sulfur isotopes, Stable Isotope Geochemistry, pp. $613 \quad 607-636$.

614 Canfield, D.E., Lyons, T.W., Raiswell, R., 1996. A model for iron deposition to euxinic Black 615 Sea sediments. American Journal of Science 296, 818-834.

616 Canfield, D.E., Poulton, S.W., Knoll, A.H., Narbonne, G.M., Ross, G., Goldberg, T., Strauss, H., 617 2008. Ferruginous conditions dominated later neoproterozoic deep-water chemistry. 618 Science 321, 949-952.

619 Canfield, D.E., Poulton, S.W., Narbonne, G.M., 2007. Late-Neoproterozoic deep-ocean 620 oxygenation and the rise of animal life. Science 315, 92-95.

621 Canfield, D.E., Raiswell, R., Bottrell, S., 1992. The reactvity of sedimentary iron minerals 622 towards sulfide. American Journal of Science 292, 659-683.

623 Canfield, D.E., Raiswell, R., Westrich, J.T., Reaves, C.M., Berner, R.A., 1986. The use of 624 chromium reduction in the analysis of reduced inorganic sulfurin sediments and shales. 625 Chemical Geology 54, 149-155.

626 Canfield, D.E., Teske, A., 1996. Late Proterozoic rise in atmospheric oxygen concentration 627 inferred from phylogenetic and sulphur-isotope studies. Nature 382, 127-132.

628 Claypool, G.E., Holser, W.T., Kaplan, I.R., Sakai, H., Zak, I., 1980. The age curves of sulfur and 629 oxygen isotopes in marine sulfate and their mutual interpretation. Chemical Geology 28, $630 \quad 199-260$.

631 Cloud, P.E., Drake, E.T., 1968. Pre-metazoan evolution and the origins of the Metazoa. 632 Evolution and environment: a symposium., 1-72. 
633 Cohen, P.A., Knoll, A.H., Kodner, R.B., 2009. Large spinose microfossils in Ediacaran rocks as 634 resting stages of early animals. Proceedings of the National Academy of Sciences of the 635 United States of America 106, 6519-6524.

636 Dahl, T.W., Hammarlund, E.U., Anbar, A.D., Bond, D.P.G., Gill, B.C., Gordon, G.W., Knoll, A.H., 637 Nielsen, A.T., Schovsbo, N.H., Canfield, D.E., 2010. Devonian rise in atmospheric oxygen 638 correlated to the radiations of terrestrial plants and large predatory fish. Proceedings of the 639 National Academy of Sciences of the United States of America 107, 17911-17915.

640 Diaz, R.J., Rosenberg, R., 1995. Marine benthic hypoxia: A review of its ecological effects and 641 the behavioural responses of benthic macrofauna, in: Ansell, A.D., Gibson, R.N., Barnes, M. 642 (Eds.), Oceanography and Marine Biology - an Annual Review, Vol 33, pp. 245-303.

643 Erwin, D.H., Laflamme, M., Tweedt, S.M., Sperling, E.A., Pisani, D., Peterson, K.J., 2011. The 644 Cambrian Conundrum: Early Divergence and Later Ecological Success in the Early History 645 of Animals. Science 334, 1091-1097.

646 Fedonkin, M., Simonetta, A., Ivantsov, A.Y., 2007. New data on Kimberella, the Vendian 647 mollusc-like organism (White Sea region, Russia): palaeoecological and evolutionary 648 implications. Geological Society Special Publication 286, 157-179.

649 Fedonkin, M.A., Waggoner, B.M., 1997. The Late Precambrian fossil Kimberella is a mollusc650 like bilaterian organism. Nature 388, 868-871.

651 Fike, D.A., Grotzinger, J.P., 2008. A paired sulfate-pyrite $\delta^{34} S$ approach to understanding the 652 evolution of the Ediacaran-Cambrian sulfur cycle. Geochimica Et Cosmochimica Acta 72, $653 \quad 2636-2648$.

654 Fike, D.A., Grotzinger, J.P., Pratt, L.M., Summons, R.E., 2006. Oxidation of the Ediacaran 655 Ocean. Nature 444, 744-747. 
656 Garrels, R.M., Lerman, A., 1981. Phanerozoic cycles of sedimentary carbon and sulfur.

657 Proceedings of the National Academy of Sciences of the United States of America-Physical 658 Sciences 78, 4652-4656.

659 Goldberg, T., Poulton, S.W., Strauss, H., 2005. Sulphur and oxygen isotope signatures of late 660 Neoproterozoic to early Cambrian sulphate, Yangtze Platform, China: Diagenetic

661 constraints and seawater evolution. Precambrian Research 137, 223-241.

662 Grazhdankin, D.V., 2003. Structure and depositional environment of the Vendian Complex

663 in the southeastern White Sea area. Stratigraphy and Geological Correlation 11, 313-331.

664 Grey, K., 2005. Ediacaran palynology of Australia. Memoirs of the Association of

665 Australasian Palaeontologists 31, 1-439.

666 Grey, K., Calver, C.R., 2007. Correlating the Ediacaran of Australia. Geological Society Special 667 Publication 286, 115-135.

668 Grey, K., Walter, M.R., Calver, C.R., 2003. Neoproterozoic biotic diversification: Snowball 669 Earth or aftermath of the Acraman impact? Geology 31, 459-462.

670 Habicht, K.S., Gade, M., Thamdrup, B., Berg, P., Canfield, D.E., 2002. Calibration of sulfate 671 levels in the Archean Ocean. Science 298, 2372-2374.

672 Halverson, G.P., Hurtgen, M.T., 2007. Ediacaran growth of the marine sulfate reservoir. 673 Earth and Planetary Science Letters 263, 32-44.

674 Hayes, J.M., 2001. Fractionation of carbon and hydrogen isotopes in biosynthetic processes, 675 Stable Isotope Geochemistry, pp. 225-277.

676 Hayes, J.M., Strauss, H., Kaufman, A.J., 1999. The abundance of ${ }^{13} \mathrm{C}$ in marine organic matter 677 and isotopic fractionation in the global biogeochemical cycle of carbon during the past 800 678 Ma. Chemical Geology 161, 103-125. 
679 Hedges, J.I., Keil, R.G., 1995. Sedimentary organic matter preservation - an assessment and 680 speculative synthesis. Marine Chemistry 49, 81-115.

681 Hoffman, P.F., Kaufman, A.J., Halverson, G.P., Schrag, D.P., 1998. A Neoproterozoic snowball 682 earth. Science 281, 1342-1346.

683 Hurtgen, M.T., Arthur, M.A., Suits, N.S., Kaufman, A.J., 2002. The sulfur isotopic composition 684 of Neoproterozoic seawater sulfate: implications for a snowball Earth? Earth and Planetary 685 Science Letters 203, 413-429.

686 Hurtgen, M.T., Halverson, G.P., Arthur, M.A., Hoffman, P.F., 2006. Sulfur cycling in the 687 aftermath of a 635-Ma snowball glaciation: Evidence for a syn-glacial sulfidic deep ocean. 688 Earth and Planetary Science Letters 245, 551-570.

689 Ingall, E., Jahnke, R., 1994. Evidence for enhanced phosphorus regeneration from marine 690 sediments overlain by oxygen depleted waters. Geochimica Et Cosmochimica Acta 58, $691 \quad 2571-2575$.

692 Jiang, G., Kaufman, A.J., Christie-Blick, N., Zhang, S., Wu, H., 2007. Carbon isotope variability 693 across the Ediacaran Yangtze platform in South China: Implications for a large surface-to694 deep ocean delta C-13 gradient. Earth and Planetary Science Letters 261, 303-320.

695 Jilbert, T., Slomp, C.P., Gustafsson, B.G., Boer, W., 2011. Beyond the Fe-P-redox connection: 696 preferential regeneration of phosphorus from organic matter as a key control on Baltic Sea 697 nutrient cycles. Biogeosciences 8, 1699-1720.

698 Johnston, D.T., 2011. Multiple sulfur isotopes and the evolution of Earth's surface sulfur 699 cycle. Earth-Science Reviews 106, 161-183.

700 Johnston, D.T., Macdonald, F.A., Gill, B.C., Hoffman, P.F., Schrag, D.P., 2012. Uncovering the

701 Neoproterozoic carbon cycle. Nature 483, 320-U110. 
702 Johnston, D.T., Poulton, S.W., Dehler, C., Porter, S., Husson, J., Canfield, D.E., Knoll, A.H., 2010.

703 An emerging picture of Neoproterozoic ocean chemistry: Insights from the Chuar Group,

704 Grand Canyon, USA. Earth and Planetary Science Letters 290, 64-73.

705 Johnston, D.T., Wing, B.A., Farquhar, J., Kaufman, A.J., Strauss, H., Lyons, T.W., Kah, L.C.,

706 Canfield, D.E., 2005. Active microbial sulfur disproportionation in the Mesoproterozoic.

707 Science 310, 1477-1479.

708 Kah, L.C., Bartley, J.K., 2011. Protracted oxygenation of the Proterozoic biosphere.

709 International Geology Review 53, 1424-1442.

710 Kampschulte, A., Strauss, H., 2004. The sulfur isotopic evolution of Phanerozoic seawater

711 based on the analysis of structurally substituted sulfate in carbonates. Chemical Geology

$712 \quad 204,255-286$.

713 Kaufman, A.J., Jiang, G.Q., Christie-Blick, N., Banerjee, D.M., Rai, V., 2006. Stable isotope

714 record of the terminal Neoproterozoic Krol platform in the Lesser Himalayas of northern

715 India. Precambrian Research 147, 156-185.

716 Keil, R.G., Montlucon, D.B., Prahl, F.G., Hedges, J.I., 1994. Sorptive preservation of labile

717 organic matter in marine sediments. Nature 370, 549-552.

718 Kendall, B., Reinhard, C.T., Lyons, T., Kaufman, A.J., Poulton, S.W., Anbar, A.D., 2010.

719 Pervasive oxygenation along late Archaean ocean margins. Nature Geoscience 3, 647-652.

720 Kennedy, M., Droser, M., Mayer, L.M., Pevear, D., Mrofka, D., 2006. Late Precambrian

721 oxygenation; Inception of the clay mineral factory. Science 311, 1446-1449.

722 Knoll, A.H., 1994. Proterozoic and early Cambrian protists - evidence for accelerating

723 evolutionary tempo. Proceedings of the National Academy of Sciences of the United States

724 of America 91, 6743-6750. 
725 Knoll, A.H., 2011. The Multiple Origins of Complex Multicellularity, in: Jeanloz, R.F.K.H.

726 (Ed.), Annual Review of Earth and Planetary Sciences, Vol 39, pp. 217-239.

727 Knoll, A.H., Hayes, J.M., Kaufman, A.J., Swett, K., Lambert, I.B., 1986. Secular variation in

728 carbon isotope ratios from upper Proterozoic successions of Svalbard and east Greenland.

729 Nature 321, 832-838.

730 Kraal, P., Slomp, C.P., de Lange, G.J., 2010. Sedimentary organic carbon to phosphorus ratios

731 as a redox proxy in Quaternary records from the Mediterranean. Chemical Geology 277,

$732 \quad 167-177$.

733 Levin, L.A., 2003. Oxygen minimum zone benthos: Adaptation and community response to

734 hypoxia. Oceanography and Marine Biology, Vol 41 41, 1-45.

735 Li, C., Love, G.D., Lyons, T.W., Fike, D.A., Sessions, A.L., Chu, X.L., 2010. A Stratified Redox

736 Model for the Ediacaran Ocean. Science 328, 80-83.

737 Logan, G.A., Hayes, J.M., Hieshima, G.B., Summons, R.E., 1995. Terminal Proterozoic

738 reorganization of biogeochemical cycles. Nature 376, 53-56.

739 Lyons, T.W., Severmann, S., 2006. A critical look at iron paleoredox proxies: New insights

740 from modern euxinic marine basins. Geochimica Et Cosmochimica Acta 70, 5698-5722.

741 Lyons, T.W., Werne, J.P., Hollander, D.J., Murray, R.W., 2003. Contrasting sulfur

742 geochemistry and Fe/Al and Mo/Al ratios across the last oxic-to-anoxic transition in the

743 Cariaco Basin, Venezuela. Chemical Geology 195, 131-157.

744 Martin, M.W., Grazhdankin, D.V., Bowring, S.A., Evans, D.A.D., Fedonkin, M.A., Kirschvink,

745 J.L., 2000. Age of Neoproterozoic bilatarian body and trace fossils, White Sea, Russia:

746 Implications for metazoan evolution. Science 288, 841-845. 
747 Marz, C., Poulton, S.W., Beckmann, B., Kuster, K., Wagner, T., Kasten, S., 2008. Redox

748 sensitivity of P cycling during marine black shale formation: Dynamics of sulfidic and

749 anoxic, non-sulfidic bottom waters. Geochimica Et Cosmochimica Acta 72, 3703-3717.

750 Maslov, A., ZM, A., LA, K., VN, P., 1994. First finds of melancyrilliums in Riphean type

751 section, southern Ural Mountains, The results, problems and perspectives of the

752 Precambrian deposits, areas, geological mapping on the territory of Russia, p. 90.

753 McFadden, K.A., Huang, J., Chu, X.L., Jiang, G.Q., Kaufman, A.J., Zhou, C.M., Yuan, X.L., Xiao,

754 S.H., 2008. Pulsed oxidation and bioloical evolution in the Ediacaran Doushantuo

755 Formation. Proceedings of the National Academy of Sciences of the United States of

756 America 105, 3197-3202.

757 Narbonne, G.M., 2005. The ediacarabiota: Neoproterozoic origin of animals and their

758 ecosystems. Annual Review of Earth and Planetary Sciences 33, 421-442.

759 Narbonne, G.M., Aitken, J.D., 1990. Ediacaran fossils from the Sekwi Brook area, Mackenzie

760 Mountains, northwest Canada. Palaeontology 33, 945-980.

761 Nesbitt, H.W., Fedo, C.M., Young, G.M., 1997. Quartz and feldspar stability, steady and non-

762 steady-state weathering, and petrogenesis of siliciclastic sands and muds. Journal of

763 Geology 105, 173-191.

764 Nesbitt, H.W., Young, G.M., 1984. Preictions of some weathering trends of plutonic and

765 volcanic rocks based on thermodynamic and kinetic considerations. Geochimica Et

766 Cosmochimica Acta 48, 1523-1534.

767 Nesbitt, H.W., Young, G.M., McLennan, S.M., Keays, R.R., 1996. Effects of chemical

768 weathering and sorting on the petrogenesis of siliciclastic sediments, with implications for 769 provenance studies. Journal of Geology 104, 525-542. 
770 Nursall, J.R., 1959. Oxygen as a prerequisite to the origin of the Metazoa. Nature 183, 1170-

7711172.

772 Ovchinnikova, G.V., Vasil'eva, I.M., Semikhatov, M.A., Gorokhov, I.M., Kuznetsov, A.B.,

773 Gorokhovskii, B.M., Levskii, L.K., 2000. The Pb-Pb trail dating of carbonates with open U-Pb

774 systems: The Min'yar Formation of the Upper Riphean stratotype, southern Urals.

775 Stratigraphy and Geological Correlation 8, 529-543.

776 Payne, J.L., McClain, C.R., Boyer, A.G., Brown, J.H., Finnegan, S., Kowalewski, M., Krause, R.A.,

777 Lyons, S.K., McShea, D.W., Novack-Gottshall, P.M., Smith, F.A., Spaeth, P., Stempien, J.A.,

778 Wang, S.C., 2011. The evolutionary consequences of oxygenic photosynthesis: a body size

779 perspective. Photosynthesis Research 107, 37-57.

780 Peterson, K.J., Butterfield, N.J., 2005. Origin of the Eumetazoa: Testing ecological

781 predictions of molecular clocks against the Proterozoic fossil record. Proceedings of the

782 National Academy of Sciences of the United States of America 102, 9547-9552.

783 Podkovyrov, V.N., Semikhatov, M.A., Kuznetsov, A.B., Vinogradov, D.P., Kozlov, V.I., Kislova,

784 I.V., 1998. Carbonate carbon isotopic composition in the upper Riphean stratotype, the

785 Karatau group, southern Urals. Stratigraphy and Geological Correlation 6, 319-335.

786 Pokrovskii, B.G., Melezhik, V.A., Bujakaite, M.I., 2006. Carbon, Oxygen, Strontium and Sulfur

787 isotopic compositons in Late Precambrian Rocks of the Patom Complex, Central Siberia.

788 Lithology and Mineral Resources, 450-474.

789 Porter, S.M., Meisterfeld, R., Knoll, A.H., 2003. Vase-shaped microfossils from the

790 Neoproterozoic Chuar Group, Grand Canyon: A classification guided by modern testate

791 amoebae. Journal of Paleontology 77, 409-429. 
792 Poulton, S.W., Canfield, D.E., 2005. Development of a sequential extraction procedure for

793 iron: implications for iron partitioning in continentally derived particulates. Chemical

794 Geology 214, 209-221.

795 Poulton, S.W., Canfield, D.E., 2011. Ferruginous Conditions: A Dominant Feature of the

796 Ocean through Earth's History. Elements 7, 107-112.

797 Poulton, S.W., Fralick, P.W., Canfield, D.E., 2004a. The transition to a sulphidic ocean similar

798 to 1.84 billion years ago. Nature $431,173-177$.

799 Poulton, S.W., Krom, M.D., Raiswell, R., 2004b. A revised scheme for the reactivity of iron

800 (oxyhydr)oxide minerals towards dissolved sulfide. Geochimica Et Cosmochimica Acta 68,

$801 \quad 3703-3715$.

802 Poulton, S.W., Raiswell, R., 2002. The low-temperature geochemical cycle of iron: From

803 continental fluxes to marine sediment deposition. American Journal of Science 302, 774-

804805.

805 Raaben, M.E., Oparenkova, L.I., 1997. New data on the Riphean stratigraphy of Timan.

806 Stratigraphy and Geological Correlation 5, 110-117.

807 Raff, R.A., Raff, E.C., 1970. Respiratory mechanisms and metazoan fossil record. Nature 228, 808 1003-\&.

809 Raiswell, R., Buckley, F., Berner, R.A., Anderson, T.F., 1988. Degree of pyritization of iron as

810 a paleoenvironmental indicator of bottom water oxygenation. Journal of Sedimentary

811 Petrology 58, 812-819.

812 Raiswell, R., Canfield, D.E., 1996. Rates of reaction between silicate iron and dissolved 813 sulfide in Peru Margin sediments. Geochimica Et Cosmochimica Acta 60, 2777-2787. 
814 Raiswell, R., Canfield, D.E., 1998. Sources of iron for pyrite formation in marine sediments.

815 American Journal of Science 298, 219-245.

816 Raiswell, R., Canfield, D.E., Berner, R.A., 1994. A comparison of iron extraction methods for

817 the determination of degree of pyritization and the recognition of iron limited pyrite

818 formation. Chemical Geology 111, 101-110.

819 Raiswell, R., Newton, R., Wignall, P.B., 2001. An indicator of water-column anoxia:

820 Resolution of biofacies variations in the Kimmeridge Clay (Upper Jurassic, UK). Journal of

821 Sedimentary Research 71, 286-294.

822 Rhoads, D.C., Morse, J.W., 1971. Evolutionary and ecologic significance of oxygen deficient

823 marine basins. Lethaia 4, 413-\&.

824 Ries, J.B., Fike, D.A., Pratt, L.M., Lyons, T.W., Grotzinger, J.P., 2009. Superheavy pyrite (delta

825 S-34(pyr) > delta S-34(CAS)) in the terminal Proterozoic Nama Group, southern Namibia: A

826 consequence of low seawater sulfate at the dawn of animal life. Geology 37, 743-746.

827 Rothman, D.H., Forney, D.C., 2007. Physical model for the decay and preservation of marine

828 organic carbon. Science 316, 1325-1328.

829 Runnegar, B., 1991. Precambrian oxygen levels estimated from the biochemistry and

830 physiology of early eukaryotes. Palaeogeography Palaeoclimatology Palaeoecology 97, 97-

831111.

832 Scott, C., Lyons, T.W., Bekker, A., Shen, Y., Poulton, S.W., Chu, X., Anbar, A.D., 2008. Tracing

833 the stepwise oxygenation of the Proterozoic ocean. Nature 452, 456-U455.

834 Seibel, B.A., Drazen, J.C., 2007. The rate of metabolism in marine animals: environmental

835 constraints, ecological demands and energetic opportunities. Philosophical Transactions of

836 the Royal Society B-Biological Sciences 362, 2061-2078. 
837 Sergeev, V.N., Precambrian microfossils in cherts: their paleobiology, classification, and

838 biostratigraphic usefulness. GEOS, Moscow, p. 280.

839 Sergeev, V.N., 2006. Precambrian microfossils in cherts: their paleobiology, classification,

840 and biostratigraphic usefulness. GEOS, Moscow, p. 280.

841 Sergeev, V.N., Knoll, A.H., Vorob'eva, N.G., 2011. Ediacaran microfossils from the Ura

842 Formation, Baikal-Patom uplift, Siberia: Taxonomy and Biostratigraphic significance.

843 Journal of Paleontology 85, 987-1011.

844 Sergeev, V.N., Seong-Joo, L., 2006. Real eukaryotes and precipitates first found in the Middle

845 Riphean stratotype, southern Urals. Stratigraphy and Geological Correlation 14, 1-18.

846 Severmann, S., Lyons, T.W., Anbar, A., McManus, J., Gordon, G., 2008. Modern iron isotope

847 perspective on the benthic iron shuttle and the redox evolution of ancient oceans. Geology

$848 \quad 36,487-490$.

849 Shen, Y.N., Zhang, T.G., Hoffman, P.F., 2008. On the coevolution of Ediacaran oceans and

850 animals. Proceedings of the National Academy of Sciences of the United States of America

$851 \quad 105,7376-7381$.

852 Sokolov, B.S., Fedonkin, M.A., 1990. The Vendian System. Springer-Verlag, Berlin.

853 Sokolov, B.S., Iwanowski, A.B., 1990. The Vendian System: Paleontology, The Vendian

854 System. Springer-Verlag, Berlin.

855 Sperling, E.A., Vinther, J., 2010. A placozoan affinity for Dickinsonia and the evolution of late

856 Proterozoic metazoan feeding modes. Evolution \& Development 12, 201-209.

857 Stanley, S.M., 1973. Ecological theory for sudden origin of multicellular life in late

858 Precambrian . Proceedings of the National Academy of Sciences of the United States of

859 America 70, 1486-1489. 
860 Swanson-Hysell, N.L., Rose, C.V., Calmet, C.C., Halverson, G.P., Hurtgen, M.T., Maloof, A.C.,

861 2010. Cryogenian Glaciation and the Onset of Carbon-Isotope Decoupling. Science 328, 608-

862611.

863 Tosca, N.J., Johnston, D.T., Mushegian, A., Rothman, D.H., Summons, R.E., Knoll, A.H., 2010.

864 Clay mineralogy, organic carbon burial, and redox evolution in Proterozoic oceans.

865 Geochimica Et Cosmochimica Acta 74, 1579-1592.

866 Turekian, K.K., Wedepohl, K.H., 1961. Distribution of the elements in some major units of

867 the Earth's crust. Geological Society of America Bulletin 72, 175-191.

868 Vaquer-Sunyer, R., Duarte, C.M., 2008. Thresholds of hypoxia for marine biodiversity.

869 Proceedings of the National Academy of Sciences of the United States of America 105, $870 \quad 15452-15457$.

871 Vorob'eva, N.G., Sergeev, V.N., Knoll, A.H., 2009a. Neoproterozoic microfossils from the

872 margin of the East European Platform and the search for a biostratigraphic model of lower

873 Ediacaran rocks. Precambrian Research 173, 163-169.

874 Vorob'eva, N.G., Sergeev, V.N., Knoll, A.H., 2009b. Neoproterozoic microfossils from the

875 northeastern margin of the East European Platform. Journal of Paleontology 83, 161-196.

876 Yin, L.M., Zhu, M.Y., Knoll, A.H., Yuan, X.L., Zhang, J.M., Hu, J., 2007. Doushantuo embryos

877 preserved inside diapause egg cysts. Nature 446, 661-663.

878 Yuan, X.L., Chen, Z., Xiao, S.H., Zhou, C.M., Hua, H., 2011. An early Ediacaran assemblage of 879 macroscopic and morphologically differentiated eukaryotes. Nature 470, 389-392. 


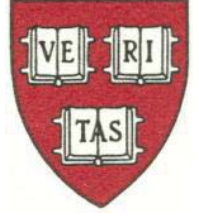

\author{
HARVARD UNIVERSITY \\ DEPARTMENT OF EARTH AND PLANETARY SCIENCES \\ 20 OXFORD ST. \\ CAMBridge, MA 02138
}

TEL. (617) 495-2351 FAX. (617) 495-8839

Highlights for Late Ediacaran redox stability and metazoan evolution by Johnston et al.

1) Redox stability, in addition to $\mathrm{O}_{2}$, is critical for animal evolution.

2) We explain Ediacaran global asynchroneity in sedimentary proxy and animals records.

3) We revisit the importance of dysoxia for biological evolution.

4) The data reinforce that Ediacaran acritarchs are resting stages of early animals. 